\title{
Evaluation of Potential for Ethanol Production from Rice Straw Using Satellite Data
}

\author{
Chiharu Hongo ${ }^{1}$, Eisaku Tamura ${ }^{1}$, I. G. A. A. Ambarawati ${ }^{2}$, I. Made Anom Wijaya ${ }^{2}$ \& A. A. A. Mirah Adi $^{2}$ \\ ${ }^{1}$ Center for Environmental Remote Sensing, Chiba University, Chiba, Japan \\ ${ }^{2}$ Udayana University, Denpasar, Indonesia \\ Correspondence: Chiharu Hongo, Center for Environmental Remote Sensing, Chiba University, 1-33 Yayoi-cho, \\ Inage-ku, Chiba, Japan. Tel: 81-43-290-3859. E-mail: hongo@faculty.chiba-u.jp
}

\author{
Received: March 7, 2017 Accepted: April 7, $2017 \quad$ Online Published: May 15, 2017 \\ doi:10.5539/jas.v9n6p22 URL: https://doi.org/10.5539/jas.v9n6p22
}

\begin{abstract}
Purpose of this study is to estimate rice yield on a plot basis with use of satellite data and field investigation data and to calculate potential quantity of rice straw to be utilized as a raw material for biofuel production in Bali, Indonesia. In addition, for continuous supply of rice straw by farmers to a biofuel producer, it is absolutely necessary to investigate farmer's interest, behavior and potential issues to solve. For this investigation, an interview was made to the subak heads. The subak is a traditional social organization consisting of farmers for managing irrigation and agriculture in the farmers' village.

The created estimation equation of rice yield had NDVI from SPOT satellite data as a predictor and was significant at $1 \%$ level. Based on the rice yield estimated through the equation and the paddy area, quantity of rice straw to be available and quantity of bioethanol to be produced were estimated. In case of Kediri, the rice straw quantity was $42,274 \mathrm{t} / \mathrm{year}$ and the ethanol quantity was $12,682 \mathrm{kl}$.

On the other hand, the handling of rice straw after harvesting was leaving/putting back to soil or burning, which accounted for $76 \%$ of the rice straw. Concerning a price of rice straw, about $60 \%$ of farmers expressed their willingness to sell at 100 rupiah ( 1 cent US\$) per $\mathrm{kg}$, and about $88 \%$ including people saying high probability seemed to think this price would be as an adequate level of sales price. Through the interview work, it becomes clear that, when some issues such as price of rice straw are settled, farmers are positive to selling of rice straw for production of biofuel.

For realizing bioethanol production from rice straw, there still remain some items to be studied further such as production process, transportation and storage system and costs. The result of our study suggests that a proposal for improvement of stable production can be made through rice yield estimation and monitoring using satellite data and that rice straw can be supplied as a promising resource of raw material for bioethanol production. This is considered to contribute the promotion of activity to reach the national goal of bioethanol production in future.
\end{abstract}

Keywords: rice straw, rice yield, biofuel, remote sensing, Indonesia, energy security

\section{Introduction}

Recently, use of biofuel has been actively promoted from viewpoints of reduction of greenhouse gas discharge and creation of new jobs in developing countries (Ramamurthi et al., 2016; Quispe et al., 2017; Singh, 2016). On the other hand, the biofuel from food such as grain crops has caused much controversy among various international organizations like OECD and FAO, researchers and experts in many countries about substantial influence over the agricultural market including sharp rise in price due to competitive relation between the biofuel and the food supply. This controversy and analysis of influence to change in price and production of agricultural products and also the food security are described in many reports such as De Gorter et al. (2016), Enciso et al. (2016), and McFarlane (2016). In addition to the influence to market, production and food security, an environmental impact is pointed out as a serious problem. Biofuel production causes change of the land use which induces change of GHG discharge and change of environment. Such changes are more serious particularly in South America and Southeast Asia. For example, in Brazil, Amazon rainforest is destroyed and converted to the farm land to increase production of crops as a raw material for biofuel production, which results in serious negative influence over to the environment. 
In Southeast Asia, more of plantation of oil palms and cassava and also cultivation of Jatropha change the land use and increase the environmental burden. Serious concern has been paid to this change (Almeida et al., 2016; Permpool et al., 2016). Under the above situation, more attention has been drawn to the use of by-product resources instead of food resources for biofuel production. Among several possible by-product resources, rice straw is expected to be promising from the fact that rice straw is very little used now and price is rather so inexpensive. In Indonesia having the most population in the ASEAN countries, the presidential decree was announced in 2006 relating to use of biofuel where the target was so described as $15 \%$ of total fuel to be consumed in transportation shall be bioethanol by 2025. Indonesia is the 3rd largest producer of rice in the world and, when the potential of bioethanol production from rice straw is calculated based on the Indonesian statistical information about rice planted area, the amount of biofuel to be produced accounts for $7.2 \%-10.7 \%$ of the national goal. This figure raises expectation to rice straw for production of biofuel, promotion of $\mathrm{CO}_{2}$ removal and creation of new jobs.

There are several effects expected to be realized through introduction of biofuel which include reduction of environmental burden, promotion of regional economy and increase in agriculture and energy security. In order to confirm these effects, evaluation on each effect based on concrete and quantitative data and indexes is necessary. One of methods for the evaluation is, for example, LCA (Life Cycle Assessment) analysis which is widely used in the world for calculating the effect of environmental burden removal. It, however, has some isuues such as time consuming work to collect inventory data for the analysis. For the evaluation of effects, if data on actual land use situation and production volume covering wide area is available, it is expected to be able to contribute to improvement of the evaluation accuracy.

Since 2009, we have been conducting research to estimate rice production volume precisely on each plot basis with use of spatial information such as satellite data in West Java and also Bali, in Indonesia (Hongo et al., 2014; Nuarsa et al., 2012; Shikata et al., 2013). As to a rice straw, most of rice straw is left in rice field or putting back to soil or burnt in the field, so the ratio of utilization of rice straw is very low.

For promoting further the utilization of by-product resources, it is important to evaluate both abundance of the by-product resources and quantity available for utilization as precisely as possible. It is also necessary to make an appropriate arrangement and system for the utilization which carefully considers local environment and social characteristics at a site for practical utilization of the resources. Remote sensing can evaluate the abundance on each pixel basis which makes it possible to do a micro-scale evaluation and also cover wide area at the same time. In addition, in developing countries, various data and information necessary to evaluate a site for biofuel plant construction is often not fully digitized and updated. This means that cost for preparation and maintenance of the necessary data and information is not negligible. Remote sensing is expected to contribute to solution of this issue.

Moreover, in Indonesia, the agricultural insurance was started for purpose to realize the sustainable agriculture in the future. For supporting promotion of the insurance, we plan to start a research project from 2017 where new method for damage assessment of rice with use of spatial information including remote sensing data is to be developed. For the damage assessment which is a core part in the agricultural insurance, the estimation and evaluation of rice yield is conducted using spatial information. The estimated yield data can be converted to potential quantity of rice straw. In other words, the data which is obtained with use of spatial information can be used for both the realization of sustainable agriculture through agricultural insurance and the biofuel production. This multiuse of data will decrease costs relating to data acquisition and usage.

For a purpose to evaluate if there would be possibility to realize the production of biofuel from rice straw in Indonesia, particularly from viewpoint of potential quantity of rice straw and supply of rice straw to the production site, we conducted research on estimation of rice yield and calculation of abundance of rice straw to be used as raw material for biofuel production. In addition, since the supply of rice straw is so important for continuous and constant production, we conducted an interview to farmers to know their interest, intention and possible issues to be solved.

\section{Materials and Methods}

\subsection{Study Area}

The research was conducted in Bali, Indonesia (Figure 1). $88 \%$ of this island is for agriculture and, when compared with $47 \%$ as an average of the whole Indonesia, this number is very high. In Bali, there are about 149,000 ha of paddy and an average yield is $5.8 \mathrm{t} / \mathrm{ha}$ which is rather higher than that in other areas. It means that Bali can have more rice straw available as unused resources for ethanol production and has good potential for production of biofuel. Bali has 8 regencies one of which is Tabanan regency where our study area is located. 
Tabanan has about $20 \%$ in size of the Bali Island and about a half of the population are farmers. One of characteristics in agriculture of Bali is the subak that is a traditional social organization (World heritage) consisting of farmers for managing irrigation and agriculture in the farmers village. Size and number of farmers in each subak is different from each other. Our study area in Tabanan has 3 districts: Kediri, Tabanan and Kerambitan having 25 subaks, 24 subaks and 23 subaks respectively. Irrigation water necessary for rice production is managed and controlled by subak (Food Crops Agriculture Department, 2006). Planting of rice is done concurrently in each subak. This makes it a lot easier to apply remote sensing to get data when compared with other rice producing areas in Indonesia (Nuarsa et al., 2010, 2011).

Tabanan regency is the largest rice production area in Bali. It has 2 seasons: a rainy season from October to March and a dry season from April to September. Due to the tropical climate, they can have 2 times of rice harvesting a year and, at the 3rd harvesting, some farmers change cultivation from rice to soy or maize as field rotation crops.

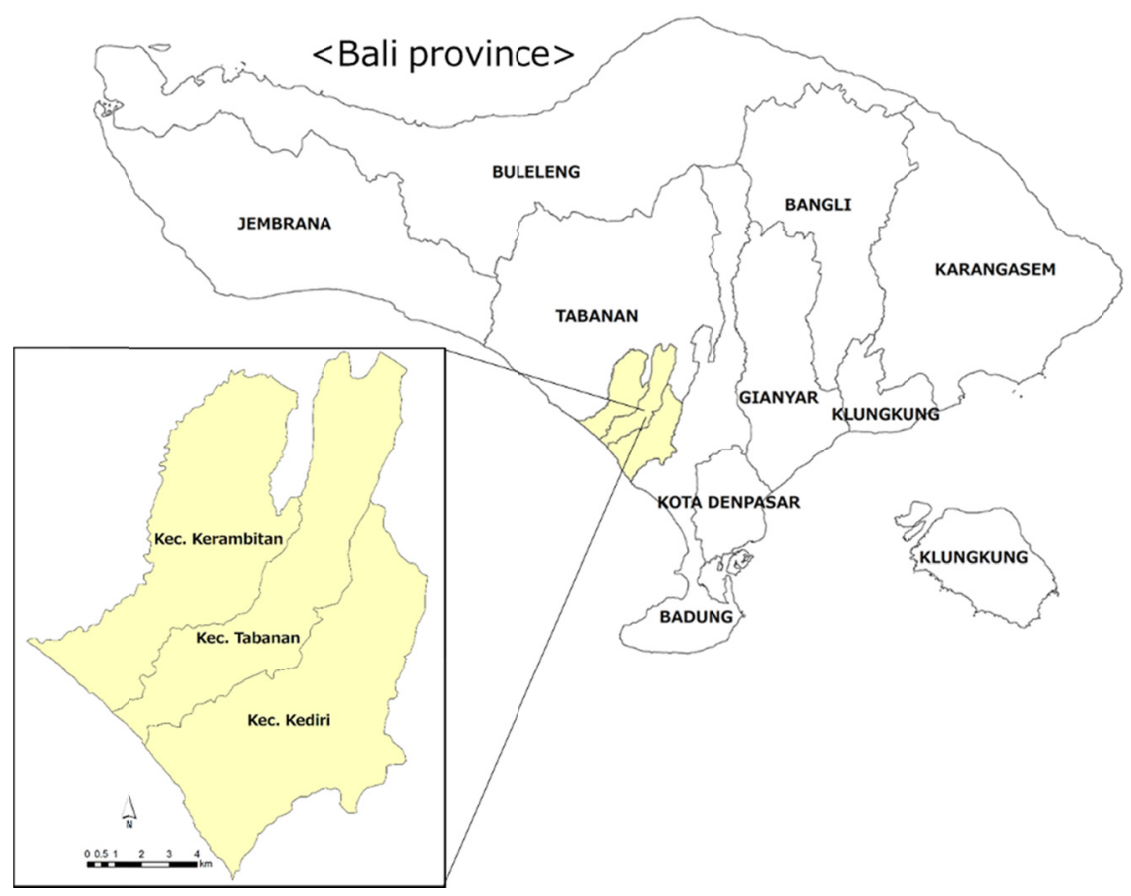

Figure 1. Study area

\subsection{Data for Analysis}

\subsubsection{Field Investigation Data of Rice Yield}

Field investigation and sampling were conducted from September 2 to 6, 2013. The sampling of rice was made on locations to be selected in paddy fields which were just before harvesting situation. Total number of the selected locations for the sampling was 40 . At each location, total 9 rice hills were harvested and unhulled rice was separated from rice plants. Then, fresh weight of both unhulled rice and rice straw was measured. Finally, using the measured weight and planting density of rice hill on the location, weight of unhulled rice and rice straw per hector was calculated.

\subsubsection{Satellite Data}

SPOT 5 image taken on August 25, 2013 was used for estimation of rice yield and an amount of rice straw to be obtained. Resolution of SPOT 5 image is $10 \mathrm{~m}$ for green band $(500-590 \mathrm{~nm})$, red band $(610-680 \mathrm{~nm})$, near infrared band $(780-890 \mathrm{~nm})$ and $20 \mathrm{~m}$ for short-wavelength infrared band.

\subsubsection{Interview to Head of Subak}

Total 37 subaks were selected for the interview which was about $50 \%$ of total subaks in Kediri, Tabanan, and Kerambitan and the interview was conducted to the head of the selected subaks. The number of the subaks in 
each district was 13 in Kediri, 12 in Tabanan and 12 in Kerambitan. Interviewing items were so selected and designed to be able to clarify the current use of rice straw, farmers' interest, willingness to supply rice straw, possible issues or worries, wish for future use of rice straw, school carrier of subak members and others.

\subsection{Procedure of Data Analysis}

Data analysis consists of 3 parts which are extraction of paddy ready for harvesting, estimation of rice yield and calculation of rice straw amount and expected bioethanol production amount (Figure 2).

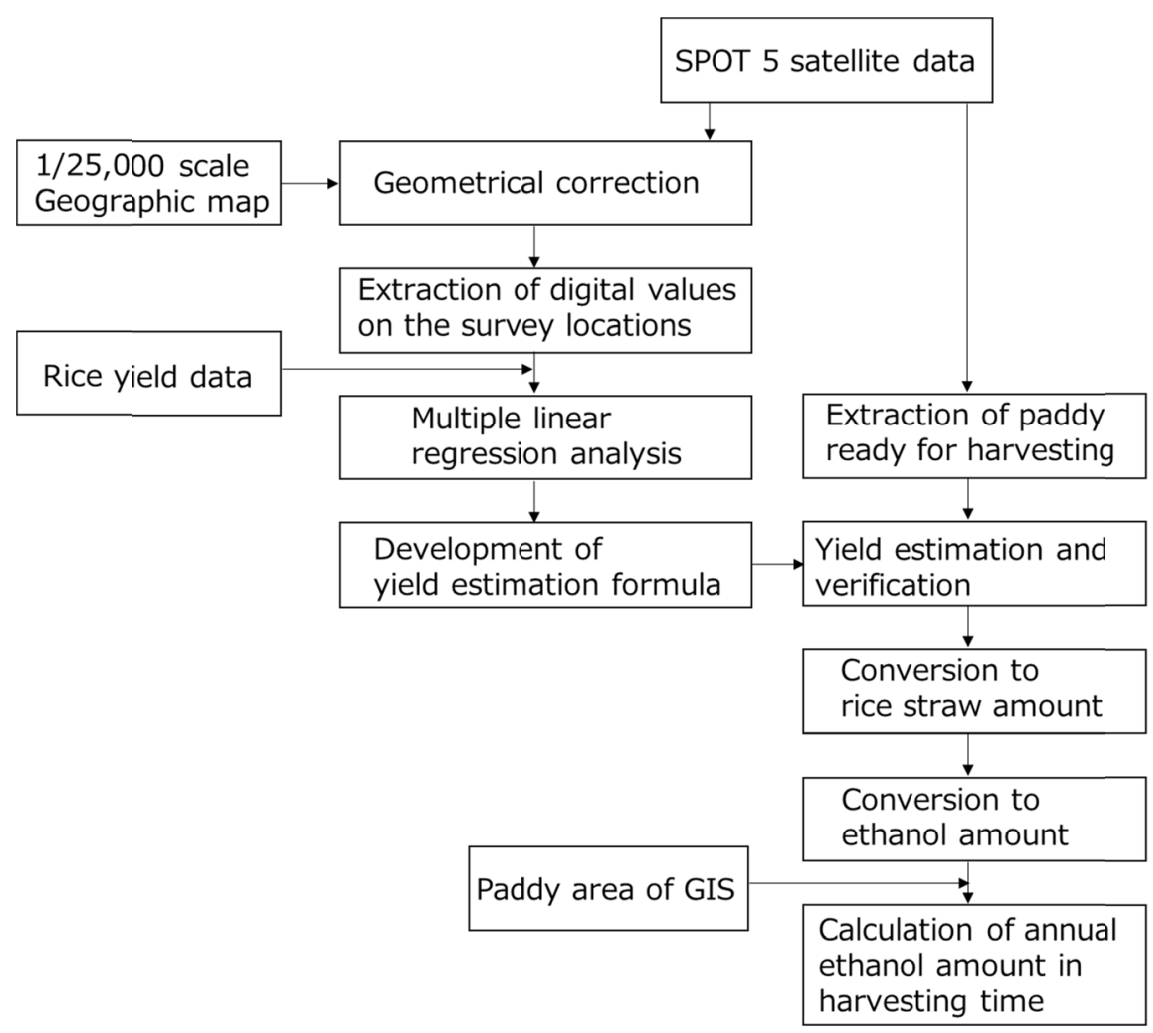

Figure 2. Procedure of data analysis

\subsubsection{Extraction of Paddy Fields Ready for Harvesting}

At first, satellite data was rectified using geographic map with scale of $1 / 25,000$ by the nearest neighbor resampling algorithm on the selected ground control points. Then, for extracting paddy field only from the satellite data, unsupervised classification was conducted on a series of input raster bands using the Iso Cluster method. The classified paddy fields included several different growth stages of rice, such as seedling stage, heading stage and harvesting stage. So, for extracting the fields just before harvesting only, supervised classification method was applied to the classified fields with use of data obtained in the field investigation work at the selected locations in the paddy ready for harvesting. As a result of the classification, all classes having the investigation locations were picked up as the paddy just before harvesting. Then, a mask file of such paddy was prepared.

\subsubsection{Estimation of Rice Yield}

Digital values on the investigation locations of paddy were extracted from satellite data. For development of a formula to estimate rice yield, multiple linear regression analysis was conducted with the digital values of green, red and infrared bands, NDVI, GNDVI and NDWI.

Definition of NDVI, GNDVI and NDWI is described as follows:

NDVI: Normalized Difference Vegetation Index $=(\mathrm{NIR}-\mathrm{R}) /(\mathrm{NIR}+\mathrm{R})$

GNDVI: Green: Normalized Difference Vegetation Index $=(\mathrm{NIR}-\mathrm{G}) /(\mathrm{NIR}+\mathrm{G})$

NDWI: Normalized Difference Water Index $=(\operatorname{SWIR}-\mathrm{R}) /(\mathrm{SWIR}+\mathrm{R})$ 
Where, R: Visible red radiation; G: Visible green radiation; NIR: Near infrared radiation; SWIR: Shortwave infrared radiation.

The formula for estimation was verified through 10 -fold cross-validation by random data partitioning and predictive error of the formula was calculated using the estimated yield and the field investigation data. Lastly, the estimation formula was applied to the SPOT data. Visualization of the result was made to show spatial distribution of yield.

\subsubsection{Estimation of Potential Quantity of Rice Straw and Ethanol}

Potential quantity of rice straw to be available in a year (DM: t/year) was calculated as below:

$$
\begin{aligned}
& \mathrm{dm}=\mathrm{Yi} \times(\text { ratio of unhalled rice to straw }) \times(1-\text { water content }) \\
& \mathrm{DM}=\mathrm{dm} \times(\text { paddy field area }) \times(\text { number of harvesting per year })
\end{aligned}
$$

Where, $\mathrm{dm}$ is a potential quantity of rice straw expected to be obtained per harvesting (t/ha), and $\mathrm{Yi}$ is an estimated production amount ( $\mathrm{t} / \mathrm{ha})$.

Ratio of unhulled rice to straw was set as 3.19 on basis of the field investigation result, and the water content was set to be $60 \%$. Paddy area was calculated on basis of GIS of the paddy field.

An average number of harvesting time per year is almost 3 times a year, depending of places and year, sometimes 2 times a year. Therefore, in average, 2.5 times was used for the calculation.

Potential quantity of bioethanol available from rice straw (Be: kl) was calculated through the following formula,

$$
\mathrm{Be}=\mathrm{DM} \times(\text { unused ratio }) \times(\text { conversion efficiency })
$$

Where, the unused ratio was set as $100 \%$, considering the fact that rice straw was very little utilized and the conversion efficiency is set as $30 \%$ (This percentage is the theoretical value of ethanol production efficiency from cellulose through saccharification process).

\section{Results and discussion}

\subsection{Extraction of Paddy Field Ready for Harvesting}

The study area was classified to 40 classes by the unsupervised classification method. Figure 3 shows the classified result. The 40 classes have different land use situation including paddy at panicle formation stage, heading stage, ripening stage, harvesting stage and non-paddy. The investigation work was done only in the paddy fields which were just before harvesting. So, 5 classes where the investigation was done were judged as the paddy at harvesting stage and extracted. Then, the map of paddy ready for harvesting stage was created (Figure 4). The paddy at harvesting stage was $12.5 \%$ of total paddy in the study area.

On each of pixels including this stage of paddy, estimation of rice was made as is described in section 3.2 below and, in following section 3.3 below, average potential quantity of rice straw per hectare was calculated and then, putting the rice straw quantity into an equation to get ethanol amount, estimation of ethanol to be produced was conducted. 


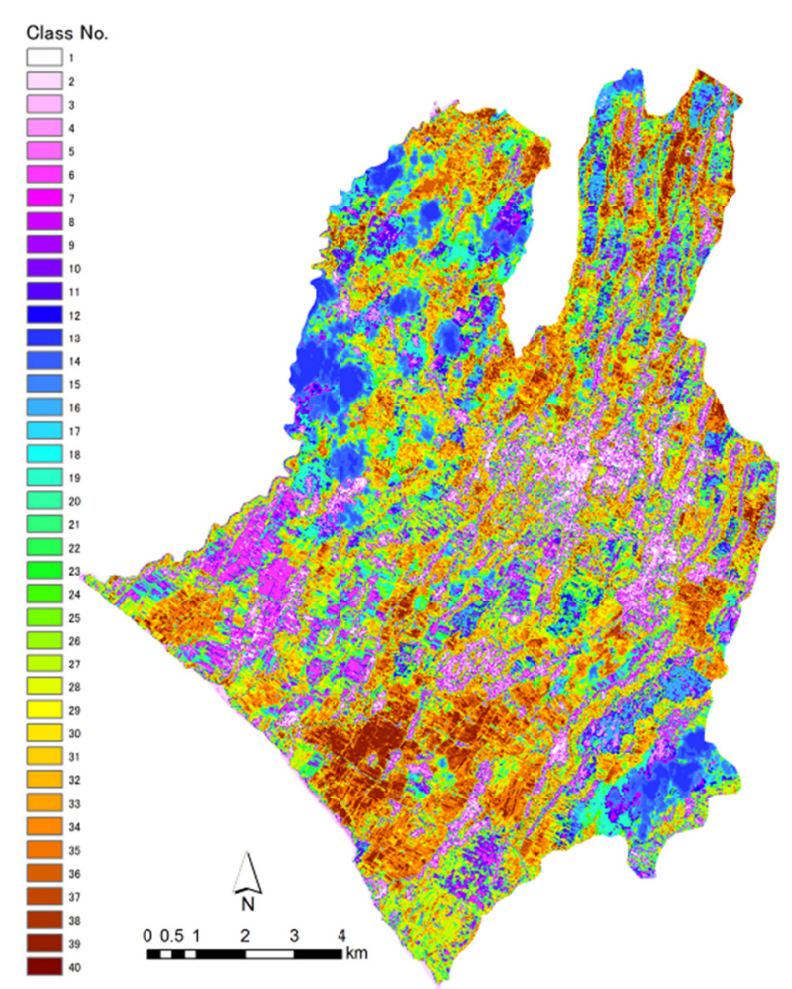

Figure 3. Result of unsupervised classification

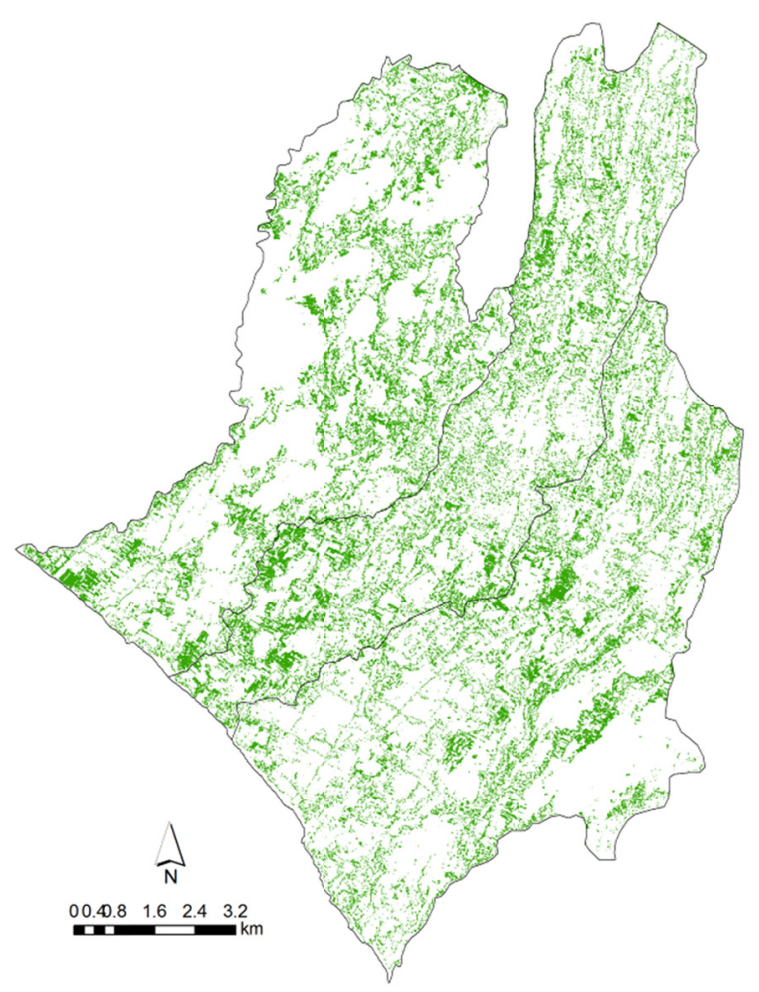

Figure 4. Map of paddy fields ready for harvesting 


\subsection{Estimation of Rice Yield}

Equations for estimating rice yield were created as a result of the multiple regression analysis with all of 7 valuables as predictors. Among the created equations, the equation with the least error had NDVI as the predictor, which is,

$$
\text { Rice yield }(\mathrm{t} / \mathrm{ha})=1377.4 \times \mathrm{NDVI}-346.4
$$

The estimation equation was validated using 10 -fold cross validation method. The estimation error was $0.57 \mathrm{t} / \mathrm{ha}$ at significant level of $1 \%$ (Figure 5). The yield estimation equation created above was put to the pixels identified in the above 3.1 section and the visualized map was developed as shown in Figure 6.

As a result of the yield estimation in all paddy fields ready for harvesting, an average yield was $4.53 \mathrm{t} / \mathrm{ha}$ in Kediri, $4.45 \mathrm{t} / \mathrm{ha}$ in Tabanan and $4.55 \mathrm{t} / \mathrm{ha}$ in Kerambitan, which were no big difference from each other (Table 1). Standard deviation was also no big difference among the 3 areas but, when seeing the yield per plot base, there were both high yield and low yield paddy plots. An average of yield in all the paddy fields was $4.52 \pm 0.65 \mathrm{t} / \mathrm{ha}$.

Bali is famous for a lot of springs of water and abundance of river water. As to timing of rice planting, the subak heads talk to each other and make a decision on basis of weather conditions such as precipitation. In each of the subaks, water management is thoroughly conducted and irrigation water is fairly distributed to all farmers according to area size of paddy by each farmer. For example, a plot-to-plot irrigation is prohibited among different farmers. Because of this specific situation and also as the result of our investigation work, no difference in yield due to lack of irrigation water could be seen. On the other hand, through our hearing investigation to extension workers, we found that there were both farmers receiving a subsidy from government and farmers not receiving it. This means that farmers receiving the subsidy could buy more fertilizers and use them in their paddy, which may give influence over the production amount and make some difference.

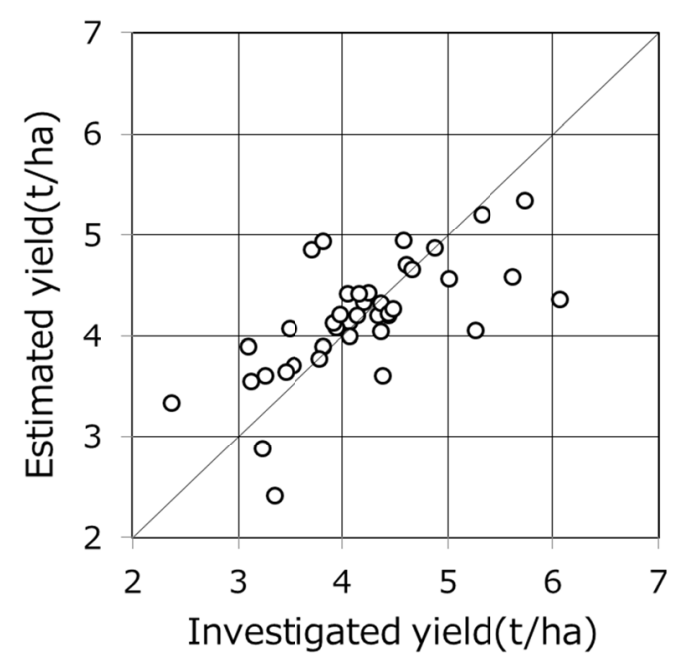

Figure 5. Relation between estimated and investigated rice yield 


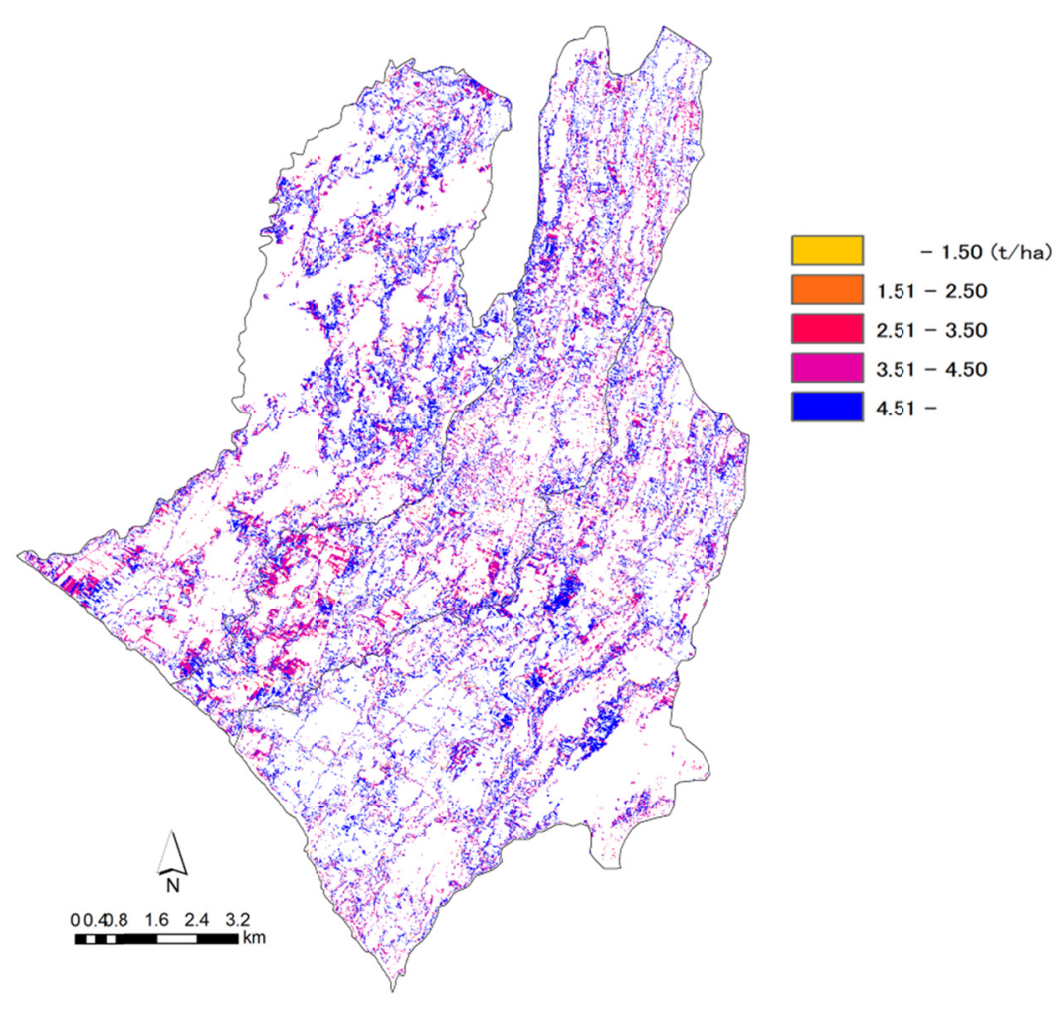

Figure 6. Map of estimated rice yield

Table 1. Average estimated yield and standard deviation in each district

\begin{tabular}{lll}
\hline Name of district & Average yield (t/ha) & Standard deviation \\
\hline Kediri & 4.53 & 0.65 \\
Tabanan & 4.54 & 0.68 \\
Kerambitan & 4.55 & 0.62 \\
\hline
\end{tabular}

\subsection{Estimation of Potential Quantity of Rice Straw and Ethanol}

Using the result of section 3.2 on the rice yield, abundance of rice straw and potential quantity of bioethanol converted from the rice straw per pixel were calculated and visualized as shown in maps of Figures 7 and 8 . At time of our investigation, an average quantity of rice straw was $6.80 \mathrm{t} / \mathrm{ha}$ in Kediri, $6.68 \mathrm{t} / \mathrm{ha}$ in Tabanan and 6.83 $\mathrm{t} / \mathrm{ha}$ in Kerambitan. An average quantity of bioethanol to be obtained from the rice straw was $0.91 \mathrm{kl} / \mathrm{ha}$ in Kediri, $0.89 \mathrm{kl} / \mathrm{ha}$ in Tabanan and $0.91 \mathrm{kl} / \mathrm{ha}$ in Kerambitan.

In order to calculate the potential quantity per year of bioethanol to be produced in the whole study area, total area of paddy in the area was necessary. However, among 3 districts: Kediri, Tabanan and Kerambitan, only Kediri had accurate data on the paddy area where they had GIS of the paddy field. So, the potential quantity of bioethanol per year was calculated only in the Kediri.

As a result of the extraction work with use of the paddy field GIS, the total paddy area in Kediri was 2,898 ha and the area of paddy ready for harvesting was 374.6 ha.

Then, annual potential quantity of bioethanol to be produced was estimated. Based on the estimated yield and paddy area, potential quantity of rice straw to be available in Kediri was estimates to be 42,274 t/year and quantity of bioethanol to be produced was $12,682 \mathrm{kl}$ on the assumption that all rice straw be converted to bioethanol through theoretical conversion equation. If this quantity of ethanol is converted to a market value, it could be about 78 billion rupiah (about 7.8 million dollars) in case a market price of gasoline is set as 6,500 rupiah per liter. And if weight of exhausted $\mathrm{CO}_{2}$ is calculated on basis of 2,360 g/l, this study result suggests possibility of substantial $\mathrm{CO}_{2}$ reduction of about $30,000 \mathrm{t}$. 


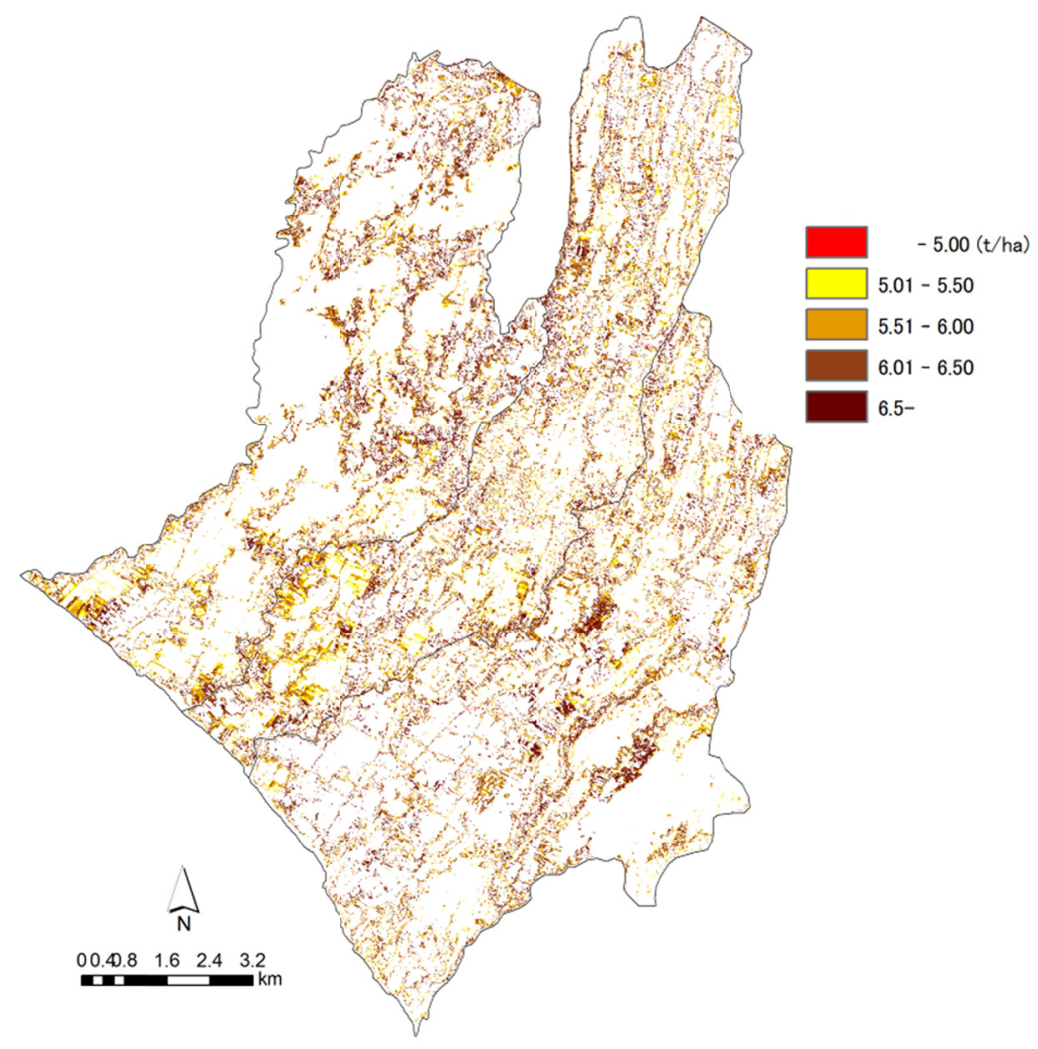

Figure 7. Map of abundance of rice straw

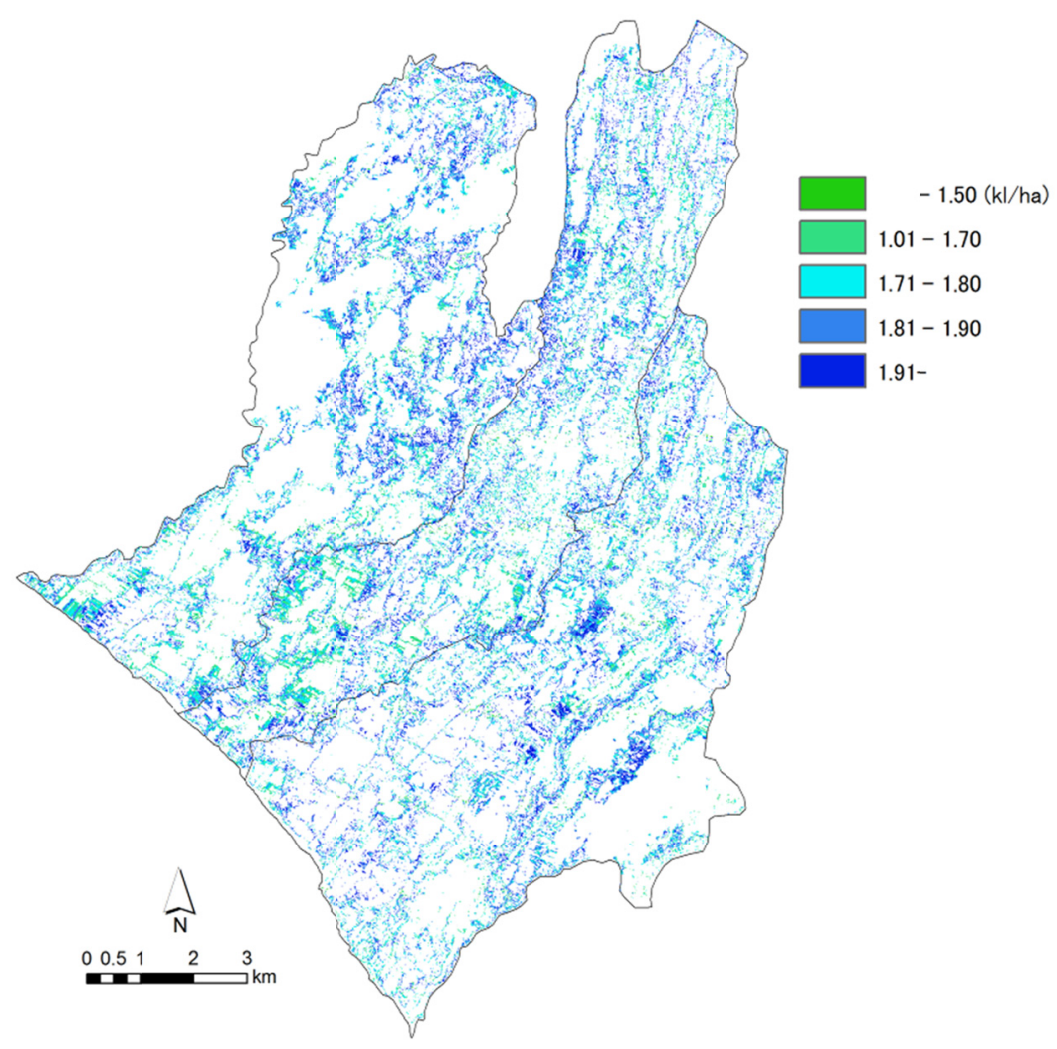

Figure 8. Map of potential quantity of bioethanol 


\subsection{Potential Use of Rice Straw for Ethanol Production in Study Area}

One of key points in evaluation of feasibility to utilize rice straw for biofuel production is to carefully investigate a farmer's interest and behavior. In other words, this question has to be asked to a farmer: whether or not a farmer is willing to sell his rice straw to a biofuel producer. For this investigation, an extensive interview to farmers was conducted who lived in the same area as one where the rice yield and potential quantity of rice straw was estimated using satellite data. In this area, about $90 \%$ of the farmer was the owner farmer and each farmer had 0.1 ha to 2.0 ha of paddy field. An average size of the owned paddy per farmer was 0.41 ha. They cultivated crops total 3 times a year. Typical cultivated crops in the study area were rice for 2 times a year and maize or soy bean as secondary crops once a year.

As is mentioned before, rice production in Bali is managed and controlled by subak, a traditional social organization and irrigation association composed of farmers. Subak has its own code which stipulates production schedule, allocation of irrigation water, participation in religious ceremony, collaborative work and others. A head of subak is elected to coordinate the whole subak activities. The subak head is a kind of absolute existence and is to negotiate with people of inside and outside the subak on basis of and on behalf of interests of all subak members. In other words, the head is to make consensus of all members' opinions and represent the subak's opinion. So, the interview was conducted to 37 subak heads in Kediri, Tabanan and Kerambitan to clarify their interest in selling of rice straw, possible issues on the selling, level of understanding about biofuel and others. The number of farmers in Kediri, Tabanan and Kerambitan were 2,986, 2,777 and 2,896 respectively (Table 2).

Table 2. Number of interviewed subak

\begin{tabular}{llll}
\hline District & Number of Subak & Number of farmer & Total area of district (ha) \\
\hline Kediri & 13 & 2986 & 1211 \\
Tabanan & 12 & 2777 & 1240 \\
Kerambitan & 12 & 2896 & 1134 \\
Total & 37 & 8659 & 3585 \\
\hline
\end{tabular}

Figure 9 shows how rice straw is handled or utilized by farmers. The highest percentage, about $50 \%$, was to put the straw back to paddy soil. Background of this high percentage was in that, according to agreement among the subak members, rice straw was plowed in paddy field after harvesting as fertilizer for purpose to increase soil fertility. This work was instructed by extension workers or done by the farmer himself. $1 / 4$ of the straw was to be burnt, particularly in Kediri. 13\% was to sell the straw for livestock feed, mushroom bed cultivation and pottery production and most of such farmers were in Kerambitan.

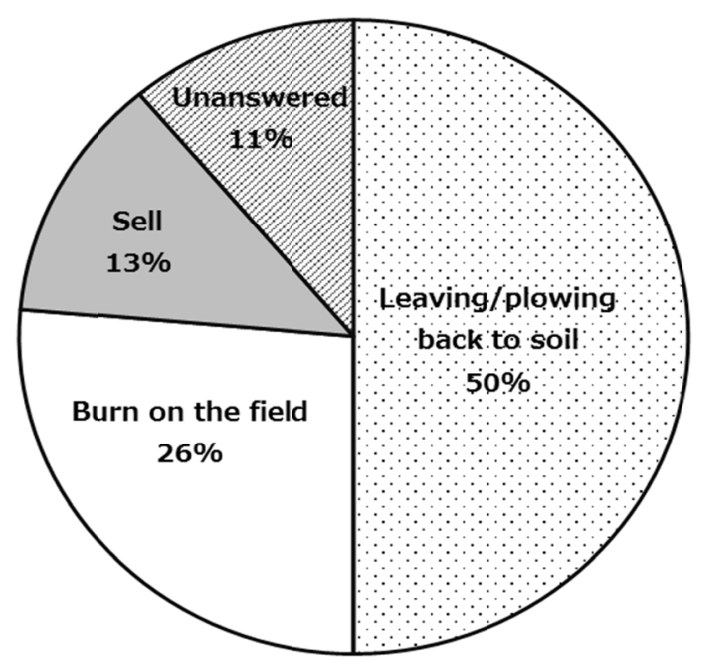

Figure 9. Utilization of rice straw 
In the interview, one of questions was if farmers would show positive interest in collecting, transporting and selling rice straw to a biofuel producer. The number of answers saying less necessity for selling rice straw was a little more than the number saying positive selling in Kediri where rice straw was burnt. In addition, in Kerambitan where more farmers were actually selling their rice straw, about $70 \%$ said less necessity for selling the straw as a resource to biofuel. On the other hand, $75 \%$ had interest in selling the straw to get side-income in Tabanan (Figure 10).

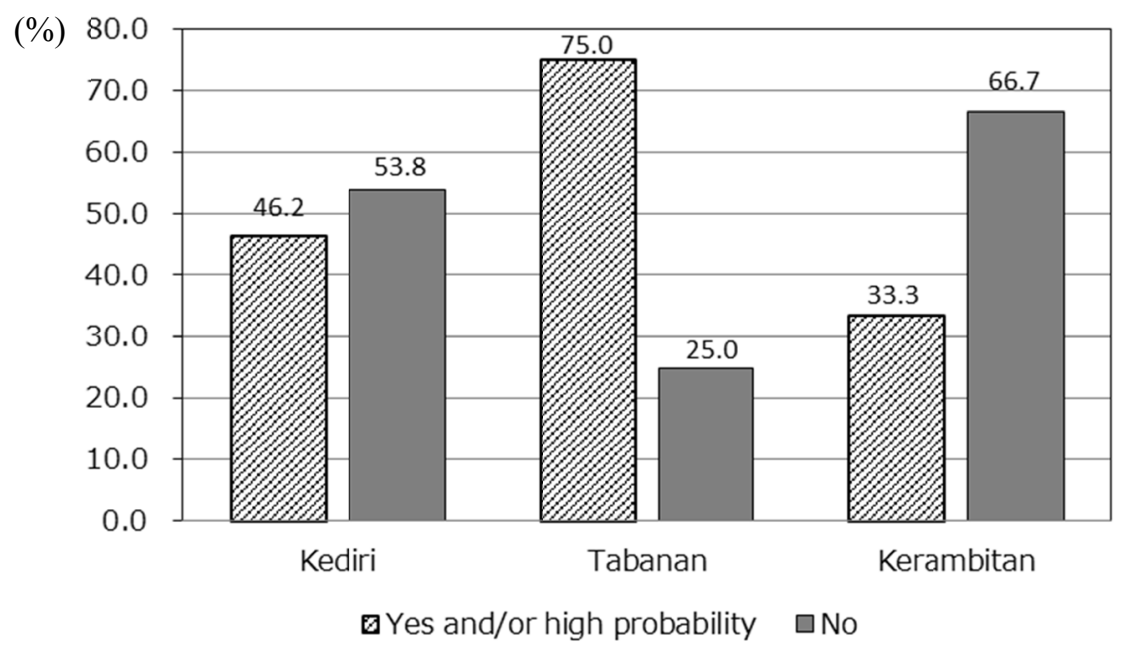

Figure 10. If rice straw can be sold, do you think farmers are willing to collect and sell it?

Concerning a price of rice straw, about $60 \%$ expressed the willingness to sell at 100 rupiah ( 1 cent US\$) per $\mathrm{kg}$, and about $88 \%$ including people saying high probability seemed to think this price as an adequate level of sales price. $100 \mathrm{rupiah} / \mathrm{kg}$ means $812,000 \mathrm{rupiah} / \mathrm{ha}$ (about $81.2 \mathrm{US} \$$ ), and, as the average of owned farming area per farmer is 0.41 ha, the farmer can get income of 332,920 rupiah (33.3 US\$) which is good income because very limited source of cash income is available to the farmer (Figure 11).

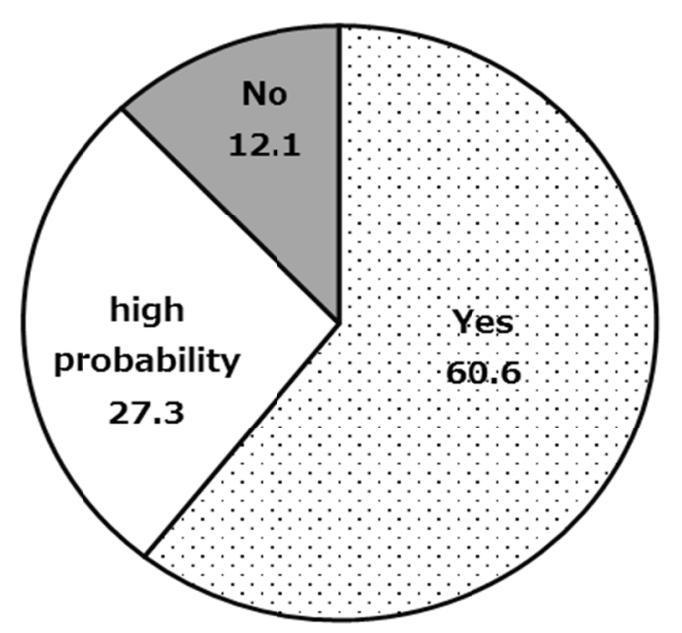

Figure 11. If rice straw is sold at $\mathrm{Rp} 100 / \mathrm{kg}$, do you agree?

Collection and transportation of rice straw is another important issue in biofuel production. Ishii et al. (2016) suggest that in Hokkaido, Japan the collection and transportation of rice straw from paddy field is a key for biofuel production and they also confirm that an economically feasible spatial scale is within a $20 \mathrm{~km}$ radius. If 
referring to this analysis result, in our study area in Bali, one stockyard should be set up in an area having 3 districts. So, we made an interview about the collection and transportation work of rice straw. In the interview, a question was given to the heads asking, "If 40,000 rupiah (about 4 US\$) is paid, the collection and transportation work would be acceptable". 54\% of the answer was positive while about $43 \%$ was negative because 40,000 rupiah was too low. Main side-income for farmers in our study area was a daily employment at construction sites and about 100,000 rupiah (about 10 US\$) could be paid per day, although there would be some difference depending on type of jobs. This is to indicate farmers' thinking and preference to select a job giving more cash (Figure 12).

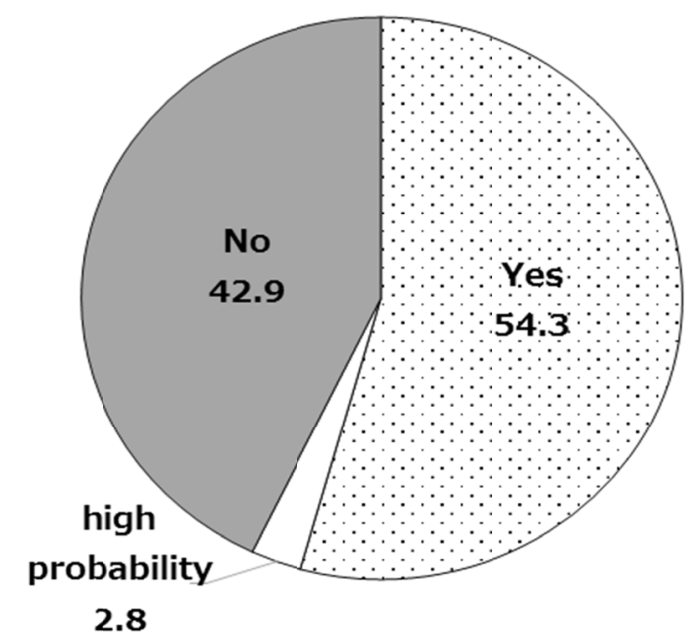

Figure 12. What about Rp 40,000 for work to collect straw?

In addition to this preference, there are some other anxiety factors such as late payment of their fee and costs for transporting the straw to a production site. It means that there are a number of farmers who feel some unexpected troubles or happenings to occur because the work for collection and transportation of their rice straw is quite new to them (Figure 13).

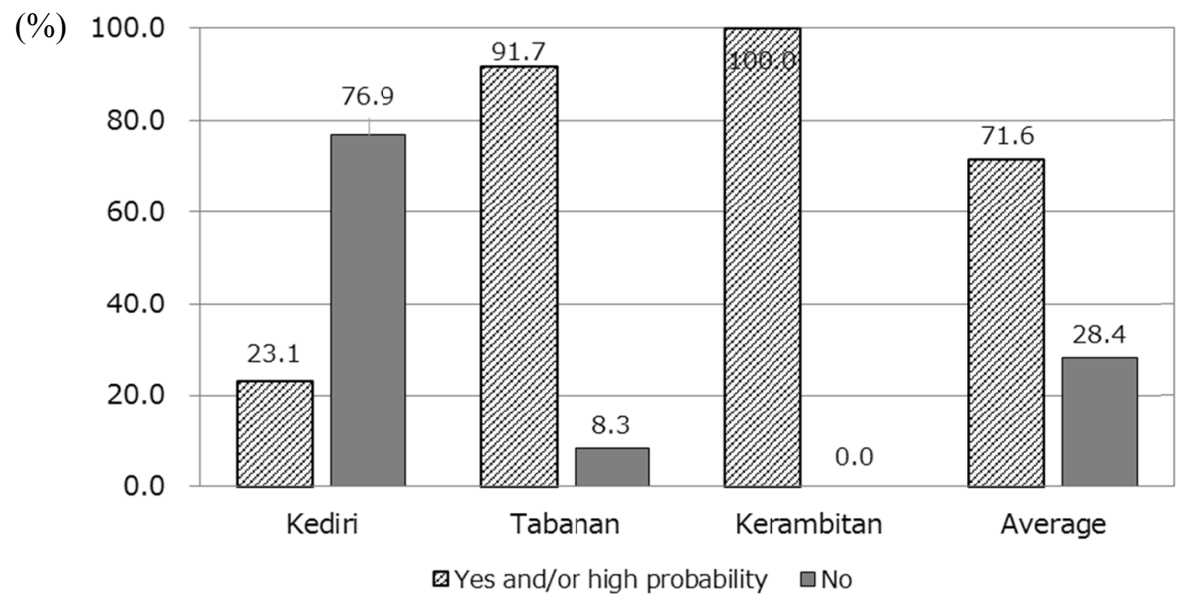

Figure 13. Do you feel any problems arise from rice straw collection?

Although there are some anxiety factors, when a following question was asked to subak heads, most of them gave positive answer back to us: "If your subak members have interest in selling their rice straw to ethanol producers, do you (as a Subak head) like to support such members to collect, transport and sell the rice straw?" 
This positive reaction is based on perception of the head that a cash income from the selling of rice straw would be of some help to improve farmers' poor life (Figure 14).

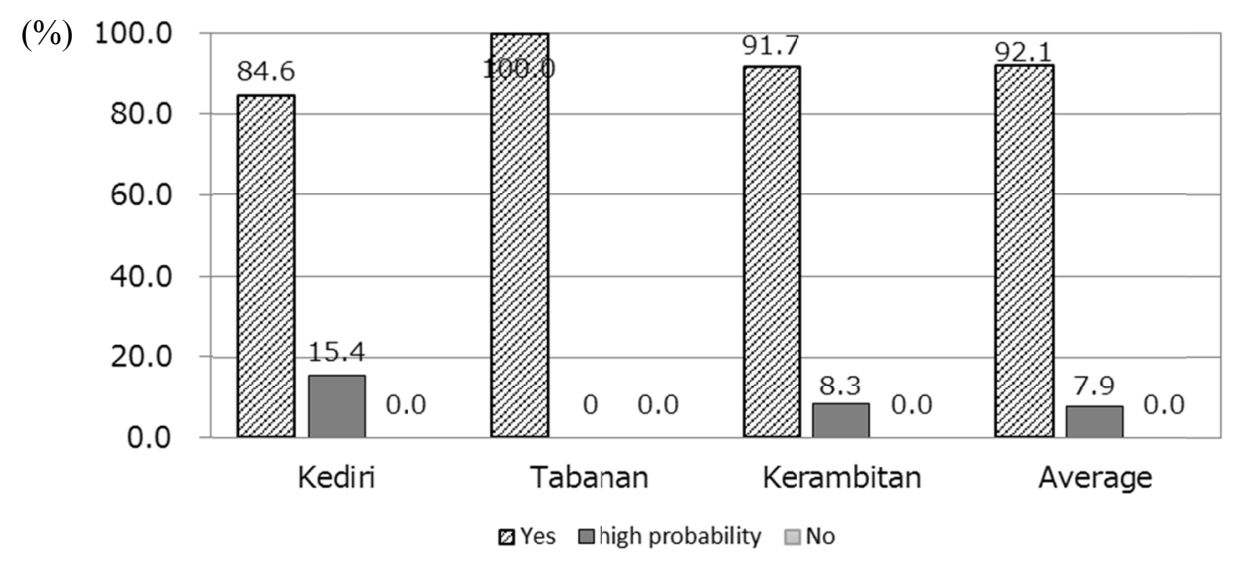

Figure 14. Do you think that selling of rice straw would contribute to improvement of farmers' life?

Through the interview work, it becomes clear that, when some issues such as price of rice straw are settled, farmers are positive to the selling of rice straw for production of biofuel.

As the next step to realize the biofuel production from rice straw, it is essential to provide all pertinent information related to biofuel production to let farmers understand that the utilization of rice straw for biofuel production can help improvement of quality of their own life and also make substantial contribution to environmental conservation. In other words, there is a need to improve farmers' knowledge not to just burn rice straw after harvesting and to utilize it to possible extent for their own benefit and also for the environment.

As a further step toward the social implementation of utilization of rice straw for biofuel, considering nature of subak and a position of subak head, it would be far more effective way to educate, at first, a subak head and convince him of all advantages of this rice straw utilization together with possible issues to be solved and also detailed procedures of collecting and transporting the straw to a biofuel producer. Then, appropriate education and training is provided to the subak members in collaboration with the head. There is a need to disseminate the use of rice straw for ethanol production to widen farmer's knowledge for the economic value of paddy's byproduct other than for the current applications.

Figure 15 below is a result of the interview on academic carrier of the subak head. More than a half of the heads are elementary school graduates, about $30 \%$ high school graduates and a few college graduates in Kerambitan. Many of farmers do not complete elementary school. Among the farmers, subak heads have relatively higher education carrier and are supposed to have more knowledge. So, for the effective social implementation, a close cooperation with a subak head is essential to get smooth acceptance by all farmers and to secure sustainable supply of rice straw to biofuel producers. 


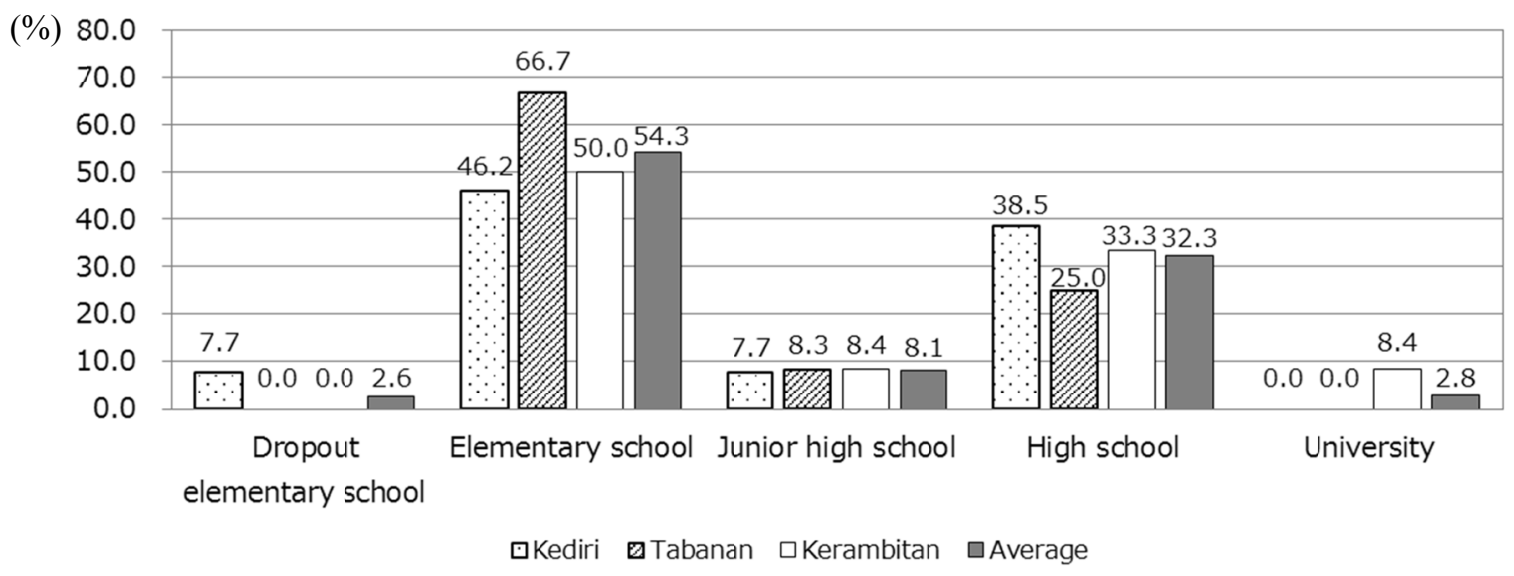

Figure 15. Interview on academic carrier of the subak head

\section{Summary}

Purpose of this study is to estimate rice yield on a plot basis with use of satellite data and field investigation data and to calculate potential quantity of rice straw to be utilized as a raw material for biofuel production in Bali, Indonesia. In addition, for continuous supply of rice straw by farmers to a biofuel producer, it is absolutely necessary to investigate farmer's interest, behavior and potential issues to solve. For this investigation, an interview was made to the subak heads. In this study, as the first step to estimate rice yield on a plot basis, SPOT satellite data was used to extract paddy field ready for harvesting by the unsupervised classification method. Then, the multiple regression analysis was conducted to create an equation for estimation of rice yield, using both data by the field investigation and data from SPOT data. The created equation had NDVI as a predictor and was significant at $1 \%$ level.

Based on the rice yield estimated through the equation and the paddy area, potential quantity of rice straw to be available and potential quantity of bioethanol to be produced were estimated. In case of Kediri, the rice straw quantity was $42,274 \mathrm{t} / \mathrm{year}$ and the ethanol quantity was $12,682 \mathrm{kl}$. This level of the quantity was promising for production of biofuel from rice straw although detailed feasibility study would be needed further.

Then, the interview to the subak heads was conducted with the result that almost all subak heads were positive to the utilization of rice straw, although some issues remained to be solved such as level of price of rice straw, because some income from the selling of rice straw would be expected to help improvement of farmer's quality of life. For stepping forward to implementation of biofuel production from rice straw, there is a need to disseminate to farmers the utilization of rice straw from both viewpoints of advantages and possible issues to solve. For the dissemination, it is far more effective to educate the subak heads at first and then to subak members in collaboration with the head. And it is also necessary to check the details of process for the biofuel production and a system for collection, transportation and storage from both technical and economical viewpoints.

To realize sustainable production of biofuel from rice straw on a long term basis, it is important to operate the production facilities most effectively and efficiently and, for the most optimal operation, a detailed production plan has to be carefully set up and also monitored through continuous estimation and evaluation of rice yield and how much quantity of rice straw would be available from where and when. For this estimation and evaluation, the remote sensing is powerful to provide pertinent spatial information continuously, covering wide area easily.

The result of our study suggests that a proposal for improvement of stable production can be made through rice yield estimation and monitoring using satellite data and that rice straw can be supplied as a promising source of raw material for bioethanol production. This is to contribute the promotion of activity to reach the national goal of bioethanol production in Indonesia. Finally, rice straw is an attractive by-product resource for production of biofuel in terms of its potential quantity, reduction of environmental burdens by removing substantial weight of $\mathrm{CO}_{2}$, contribution to food security through building up sustainable food production system and, in addition, the creation of new jobs and income source to improve farmer's quality of life by selling of rice straw. And, for making better plan and sustainable production, remote sensing and spatial information have high value to utilize. 


\section{References}

Almeida, J., De Meyer, A., Cattrysse, D., Van Orshoven, J., Achten, W. M. J., \& Muys, B. (2016). Spatial optimization of Jatropha based electricity value chains including the effect of emissions from land use change. Biomass \& Bioenergy, 90, 218-229. https://doi.org/10.1016/j.biombioe.2016.04.010

De Gorter, H., \& Drabik, D. (2016). Biofuel policies and the impact of developing countries' policy responses to the 2007-2008 food price boom. Global Food Security-Agriculture Policy Economics and Environment, 11, 64-71. https://doi.org/10.1016/j.gfs.2016.07.008

Enciso, S. R. A., Fellmann, T., Dominguez, I. P., \& Santini, F. (2016). Abolishing biofuel policies: Possible impacts on agricultural price levels, price variability and global food security. Food Policy, 61, 9-26. https://doi.org/10.1016/j.foodpol.2016.01.007

Food Crops Agriculture Department. (2006). Annual report of food crops (Vol. 3, pp. 125-130). Department Agriculture of Local Government, Bali Province, Indonesia.

Hongo, C., Gunardi, S., Shikata, R., Niwa, K., \& Tamura, E. (2014). The Use of Remotely Sensed Data for Estimating of Rice Yield Considering Soil Characteristics. Journal of Agricultural Science, 6(7), 172-184. http://dx.doi.org/10.5539/jas.v6n7p172

Ishii, K., Furuichi, T., Fujiyama, A., \& Watanabe, S. (2016). Logistics cost analysis of rice straw pellets for feasible production capacity and spatial scale in heat utilization systems: A case study in Nanporo town, Hokkaido, Japan. Biomass \& Bioenergy, 94, 155-166. https://doi.org/10.1016/j.biombioe.2016.08.007

McFarlane, I. (2016). Agricultural commodity prices and oil prices: Mutual causation. Outlook on Agriculture, 45(2), 87-93. https://doi.org/10.1177/0030727016649809

Nuarsa, I. W., Nishio, F., \& Hongo, C. (2010). Development of the empirical model for rice field distribution mapping using multi-temporal Landsat ETM+ data: Case study in Bali, Indonesia. International Archives of the Photogrammetry, Remote Sensing and Spatial Information Science, XXXVIII(8), 482-487.

Nuarsa, I. W., Nishio, F., \& Hongo, C. (2011). Relationship between rice spectral and rice yield using MODIS data. Journal of Agriculture Science, 3(2), 80-88. https://doi.org/10.5539/jas.v3n2p80

Nuarsa, I. W., Nishio, F., \& Hongo, C. (2012). Rice Yield Estimation Using Landsat ETM+ Data and Field Observation. Journal of Agricultural Science, 4(3), 45-56. http://dx.doi.org/10.5539/jas.v4n3p45

Permpool, N., Bonnet S., \& Gheewala, S. H. (2016). Greenhouse gas emissions from land use change due to oil palm expansion in Thailand for biodiesel production. Journal of Cleaner Production, 134, 532-538. https://doi.org/10.1016/j.jclepro.2015.05.048

Quispe, I., Navia, R., \& Kahhat, R. (2017). Energy potential from rice husk through direct combustion and fast pyrolysis: A review. Waste Management, 59, 200-210. https://doi.org/10.1016/j.wasman.2016.10.001

Ramamurthi, P. V., Fernandes, M. C., Nielsen, P. S., \& Nunes, C. P. (2016). Utilisation of rice residues for decentralised electricity generation in Ghana: An economic analysis. Energy, 111, 620-629. https://doi.org/ 10.1016/j.energy.2016.05.116

Shikata, R., Hongo, C., \& Gunardi, S. (2013). Analysis of relationship between the estimated rice yield and the irrigation water system in West Java. Proceedings of the International Symposium on Remote Sensing (pp. 303-306).

Singh, J. (2016). Identifying an economic power production system based on agricultural straw on regional basis in India. Renewable \& Sustainable Energy Reviews, 60, 1140-1155. https://doi.org/10.1016/j.rser.2016. 02.002

\section{Copyrights}

Copyright for this article is retained by the author(s), with first publication rights granted to the journal.

This is an open-access article distributed under the terms and conditions of the Creative Commons Attribution license (http://creativecommons.org/licenses/by/4.0/). 